\title{
Less than 1 hour
}

National Cancer Institute

\section{Source}

National Cancer Institute. Less than 1 hour. NCI Thesaurus. Code C156946.

An indication that something has lasted, occurred during, or totalled less than one hour. 